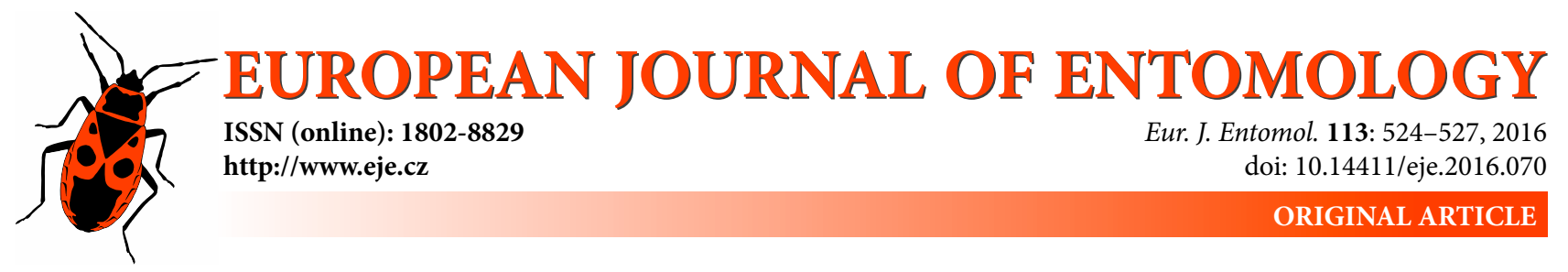

\title{
Size-related mortality during overwintering in cavity-nesting ant colonies (Hymenoptera: Formicidae)
}

\section{StaWOMIR MITRUS}

Department of Biosystematics, Laboratory of Evolution and Animal Ecology, Opole University, Oleska 22, 45-052 Opole, Poland; e-mail: smitrus@uni.opole.pl

Key words. Hymenoptera, Formicidae, Temnothorax crassispinus, survival rate, snow cover, social insects, overwintering

\begin{abstract}
The ongoing process of climate change will result in higher temperatures during winter and therefore might increase the survival of overwintering invertebrates. However, the process may also lead to a reduction in snow cover and expose overwintering invertebrates to lower temperatures, which could result in higher mortality. During a field experiment, I investigated the effects of a reduction in snow cover on the survival of the ant Temnothorax crassispinus, which overwinters in nests located on the ground. Ant colonies differed in the survival rate of the workers in the experimental (from which snow cover was removed) and control group. In the control group, the survival rate was unrelated to colony size. However, in the experimental group, from which snow was removed after each heavy snowfall, worker survival was lower in small colonies. Such colony size related mortality may affect the fusion of colonies before winter.
\end{abstract}

\section{INTRODUCTION}

For many animals living in temperate climates, physical conditions during overwintering, mostly low temperatures, cause high mortality (Leather et al., 1995; Rodenhouse et al., 2009; Bradshaw \& Holzapfel, 2010). Thus, many organisms escape such conditions, e.g. hiding underground, where temperatures are typically more favourable for surviving winter (Leather et al., 1995; Bale, 1996; Bale \& Hayward, 2010). Among others, most species of ants overwinter underground, but ants of the genus Temnothorax overwinter in nests located on the ground (Herbers, 1989; Herbers \& Johnson, 2007). Therefore, during winter, ants in such sites may be exposed to extreme temperatures. Earlier studies indicate that the mortality of the ant Temnothorax during winter may be high (Herbers \& Johnson, 2007; Mitrus, 2013), however, when winter is mild, the survival rate might be very high, and even larval development may be completed (Mitrus, 2015a).

The ongoing process of climate change will result in higher temperatures in all seasons, but the largest change in temperature is likely to occur in winter (Christensen et al., 2013). Warmer temperatures during winter could increase the chances of survival of overwintering invertebrates (e.g., Bale \& Hayward, 2010; Bradshaw \& Holzapfel, 2010; Templer et al., 2012, but see also e.g., Sorvari et al., 2011, Haatanen et al., 2015). However, climate change will probably not only affect temperature during winter, but is also likely to result in a reduction in the depth and duration of snow cover (Christensen et al., 2013; Convey et al., 2015). Such a reduction in snow cover may adversely affect survival rate, as snow cover insulates terrestrial habitats at ground level from extreme air temperatures and temperature fluctuations (Leather et al., 1995; Bale \& Hayward, 2010; Templer et al., 2012; Convey et al., 2015).

The cavity-nesting ant $T$. crassispinus is present throughout Western and Central Europe. Colonies of the ant are small, typically ranging from a few dozen to several hundred workers (Seifert, 2007; Czechowski et al., 2012). Nests of this ant are located in the litter layer, mostly in cavities in acorns, small sticks and logs (Seifert, 2007; Białas et al., 2011; Czechowski et al., 2012). Before winter colonies can unite, especially if there are only a small number of suitable nest sites (cf. Heinze, 2008). The aim of this study was to determine the effect of the reduction of snow cover on the survival of the cavity-nesting ant $T$. crassispinus.

\section{MATERIAL AND METHODS}

\section{Experimental procedure}

On the 4th and 5th of November, 2015, near Opole (southern Poland), I collected 83 nest sites (62 acorns and 21 beech sticks) containing colonies of the ant $T$. crassispinus: 52 with one queen, containing 9-321 workers (mean 141.1, quartiles: 96.5-208), and 31 without a queen, containing 9-161 workers (mean 58.0, quartiles: 30-93). Each of the colonies contained brood in the early stages of development. I transferred the colonies to square Petri dishes $(10.2 \mathrm{~cm} \times 10.2 \mathrm{~cm} \times 1.9 \mathrm{~cm})$ with a thin plaster base and artificial nest sites placed on top. The nests were made in a birch 
woodblock, with dimensions of $7 \mathrm{~cm} \times 1.8 \mathrm{~cm} \times 1.8 \mathrm{~cm}$. In each woodblock, I carved out a cavity with a volume of ca. $780 \mathrm{~mm}^{3}$ (for details, see: Mitrus, 2015a). The dishes with artificial nests were kept in a thermostatically controlled cabinet maintaining a daily cycle $10 \mathrm{~L}: 14 \mathrm{D}$, at temperatures of $16^{\circ} \mathrm{C}$ and $8^{\circ} \mathrm{C}$, respectively. From the 12th to the 20th of November, when most of the artificial nests had been occupied by the ants, the temperature was gradually decreased; the final culture regime was $10 \mathrm{~L}: 14 \mathrm{D}$, at $7^{\circ} \mathrm{C}$ and $3{ }^{\circ} \mathrm{C}$, respectively. During that time, ants were fed twice a week, with frozen fruit flies, Drosophila hydei, and honey; any dead workers found were counted and removed from the Petri dishes (0-22 workers, median 2).

After the first slight frost, on November 25, I closed the entrances to the artificial nests with a metal netting to prevent the ants from escaping. At the time, a few individuals were outside of the artificial nest sites, and several colonies did not accept the nest sites. Finally, in the field experiment I used 72 colonies: 46 with one queen and 8-312 workers (mean 134.7, quartiles: 49-201), and 26 without a queen consisting of 10-159 workers (mean 64.5, quartiles: 29-101). Colonies with queens were larger than those without queens (unequal variance $t$ test: $t^{\prime}=4.76, d f=69.87, P$ $<0.0001)$. The final days of November and the first half of December 2015 were rather warm, with daily air temperature even above $+10^{\circ} \mathrm{C}$. Thus, I delayed placing the artificial nests in the forest near Opole until the 16th of December, when the ambient temperature during the day was ca. $+5^{\circ} \mathrm{C}$.

The nests were divided randomly into six groups, and in the field they were placed in three pairs of plots. The distance between the plots in each pair was $2 \mathrm{~m}$; the three pairs of plots were separated from each other by a distance of about $20 \mathrm{~m}$. In each of the plots, 12 artificial nest with colonies were located: 7-8 nests with colonies with queens, and $4-5$ without queens. Each nest was attached to ca. $16 \mathrm{~cm}$ sticks poked into the ground; distances between the nests was $15 \mathrm{~cm}$. Previously calibrated AZ 88128 data loggers were placed on the ground near the nest sites. In addition, two such data loggers were placed on tree trunks, $1.5 \mathrm{~m}$ above ground level. Using the data loggers, the temperature was monitored at hourly intervals. Then, I covered the plots with a 16 $\mathrm{mm}$ diameter plastic net fastened to the ground with plastic pegs. Subsequently, I randomly selected from each pair of plots, an experimental ("snow-removal" plots, where the systematic removal of snow was planned) and a "control" plot ("control" plots, not to be cleared of snow). The plastic net facilitated the removal of snow cover from "snow-removal" plots.

Compared to typical winters for this part of Poland (cf. Kożuchowski, 2011; Mitrus, 2015a), the 2015/16 winter was rather warm with little snow. Thus, from the "snow-removal" plots, I removed snow cover just four times (after a snowfall, when snow completely covered the nest sites): on the 2nd, 8th, 16th and 22nd of January 2016. During the winter, even on the "control" plots, the snow cover was only present temporarily. For instance, I removed snow from the "snow-removal" plots on January 22, but as early as January 24 , nest sites at the "control" plots were partially devoid of snow cover. During the experiment, the maximum thickness of snow cover recorded in the area was only about $7 \mathrm{~cm}$.

Finally, I collected nest sites on February 26, 2016, transported them to a laboratory and placed them in a culture chamber at $5^{\circ} \mathrm{C}$. From February 29, the temperature was gradually increased to reach $10 \mathrm{~L}: 14 \mathrm{D}, 15^{\circ} \mathrm{C}$ and $5^{\circ} \mathrm{C}$, respectively, on March 10 . On that day I carefully opened the nests and counted the live individuals.

\section{Data analysis}

The survival of workers during overwintering in each colony was calculated as: (number of workers at the end of the experiment/number of workers at the beginning of the experiment) $\times 100 \%$. The general linear model (GLM) method was used to compare percentage survival of ants in "snow-removal" versus "control" groups, and for colonies with queens versus those without queens, as these colonies significantly differed in the initial number of workers. The GLM model included the initial number of workers as a covariate, and site (pairs of plots) as a blocking factor. As the distributions of the percentages of workers that survived were left skewed, before the analyses I transformed the data on survival, raising the numbers to their cubes. I carried out statistical analyses using the software package Statistica, ver. 12 (StatSoft, 2014). I used Pearson correlation coefficient when analysing relations between the number of workers and percentage survival. All probability values shown are two-tailed.

\section{RESULTS}

During winter, in periods without snow cover, the temperatures near nest sites in "snow-removal" and "control" plots were similar: recorded differences in temperatures were typically $\pm 0.4^{\circ} \mathrm{C}$. However, just after snowfall and the experimental removal of snow cover, the temperatures in "snow-removal" and "control" plots temporarily differed by up to $7.1^{\circ} \mathrm{C}$, e.g. at 19.00 on the 22 nd of January, after snow was removed in the morning of the same day, recorded temperatures were: $-9.3^{\circ} \mathrm{C}$ and $-2.2^{\circ} \mathrm{C}$ at the "snowremoval" and "control" plots, respectively (cf. Fig. 1). The minimum recorded temperature at the "snow-removal" plots was $-11.0^{\circ} \mathrm{C}$, and at the "control" plots $-9.2^{\circ} \mathrm{C}$. The minimum air temperature ( $1.5 \mathrm{~m}$ above ground level) was $-16.7^{\circ} \mathrm{C}$. The maximum temperatures recorded during the experiment were $+9.9^{\circ} \mathrm{C},+11.0^{\circ} \mathrm{C}$ and $+13.7^{\circ} \mathrm{C}$, near nest sites in the "snow-removal" plots, "control" plots, and 1.5 $\mathrm{m}$ above ground level, respectively.

On March 10, 2016, in three of the 72 nests, I found no ants, when the nests were collected on February 26, the metal netting at these three sites, which prevented the ants from escaping, had become partially detached (they included two colonies with queens and one without a queen; two from the "snow-removal" and one from the "control"

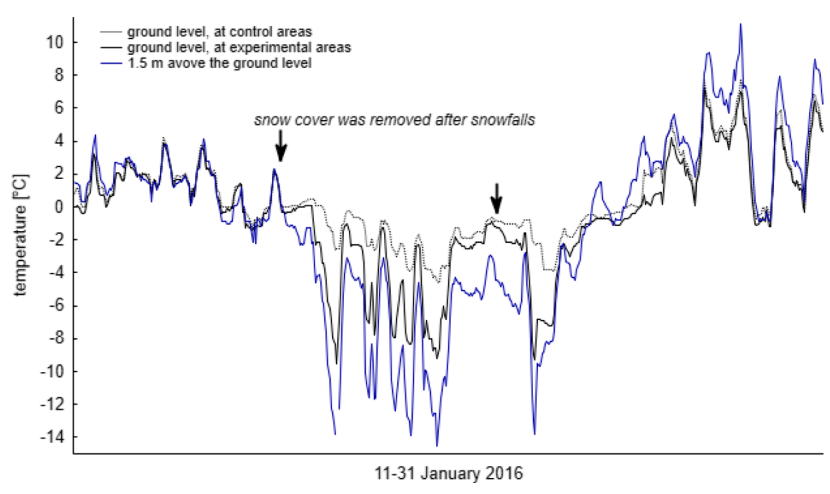

Fig. 1. Temperature changes at ground level in plots the snow cover of which was experimentally reduced (winter 2015/16, southern Poland) compared to that in "control" plots from which the snow cover was not removed. In addition, air temperature $1.5 \mathrm{~m}$ above ground is shown. Arrows indicate January 16 th and 22nd, when snow cover was removed after snowfalls. 
Table 1. Percentage of workers of the cavity-nesting ant Temnothorax crassispinus that survived overwinter. During the field experiment (mid December 2015 - end February 2016, southern Poland), snow cover was removed from experimental plots ("snow-removal" group), after each heavy snowfall, but not from the "control" group. In parenthesis: number of colonies analyzed.

\begin{tabular}{llll}
\hline & median & $\min -\max$ & quartiles \\
\hline Colonies with queens & & & \\
"snow-removal" group $(N=23)$ & 94.6 & $34.6-100.0$ & $81.2-96.5$ \\
"control" group $(N=21)$ & 93.8 & $31.1-100.0$ & $91.7-97.7$ \\
\hline Colonies without queens & & & \\
"snow-removal" group $(N=11)$ & 87.5 & $70.0-98.4$ & $78.3-95.3$ \\
"control" group $(N=14)$ & 92.7 & $66.3-100.0$ & $79.2-99.2$ \\
\hline
\end{tabular}

plots). The percentage survival of workers in the different colonies was $31.1-100.0 \%$ (Table 1 ). Only one of the 44 queens died during the winter (in a colony in a "control" plot).

There was a significant difference in the percentage survival of the workers in nests in the "snow-removal" and the "control" plots (GLM: $F_{1,60}=4.92, P=0.030$ ), and the initial number of workers affected the percentage survival $\left(F_{2,60}=4.79, P=0.012\right)$. However, the presence of a queen did not significantly affect the percentage of workers that survived $(P=0.78)$, and there was no differences between sites $(P=0.87)$. For the "snow-removal" plots, the percentage survival during the winter was correlated with the number of workers in the nest at the beginning of the experiment (Pearson's correlations: $r=0.55, N=23, P=$ 0.007 , and $r=0.66, N=11, P=0.028$, for colonies with and without queens, respectively). However, there were no such correlations for "control" plots (Pearson's correlations: $r=0.069, N=21, P=0.77$, and $r=-0.059, N=14$, $P=0.84$, for colonies with and without queens, respectively; Fig. 2).

\section{DISCUSSION}

Temnothorax crassispinus ant colonies differed in percentage mortality in the "snow-removal" (for which snow cover was removed) and "control" groups. In addition, for ant colonies in "control" plots, there was no correlation between percentage mortality and colony size. This result is consistent with previous reports (cf. Rueppell \& Kirkman, 2005; Herbers \& Johnson, 2007; Mitrus, 2015a). However, for the "snow-removal" group, worker mortality was higher in smaller colonies; such a relationship was recorded in both colonies with and without queens.

In winter, during the experiment, snow cover was present only temporarily. Previous winters in southern Poland were characterized by thin and temporary snow cover. During the 2015/2016 winter, there were only four heavy snowfalls, after which the artificial nest sites were completely covered and it was necessary to remove the snow from the "snow-removal" plots as part of the experiment. On each occasion the snow melted several days after the snowfall. Thus, the snow removal resulted simply in a reduction in the periods with snow cover. It is probable that climate change will lead to a reduction in snow cover depth and duration (Christensen et al., 2013; Convey et al.,
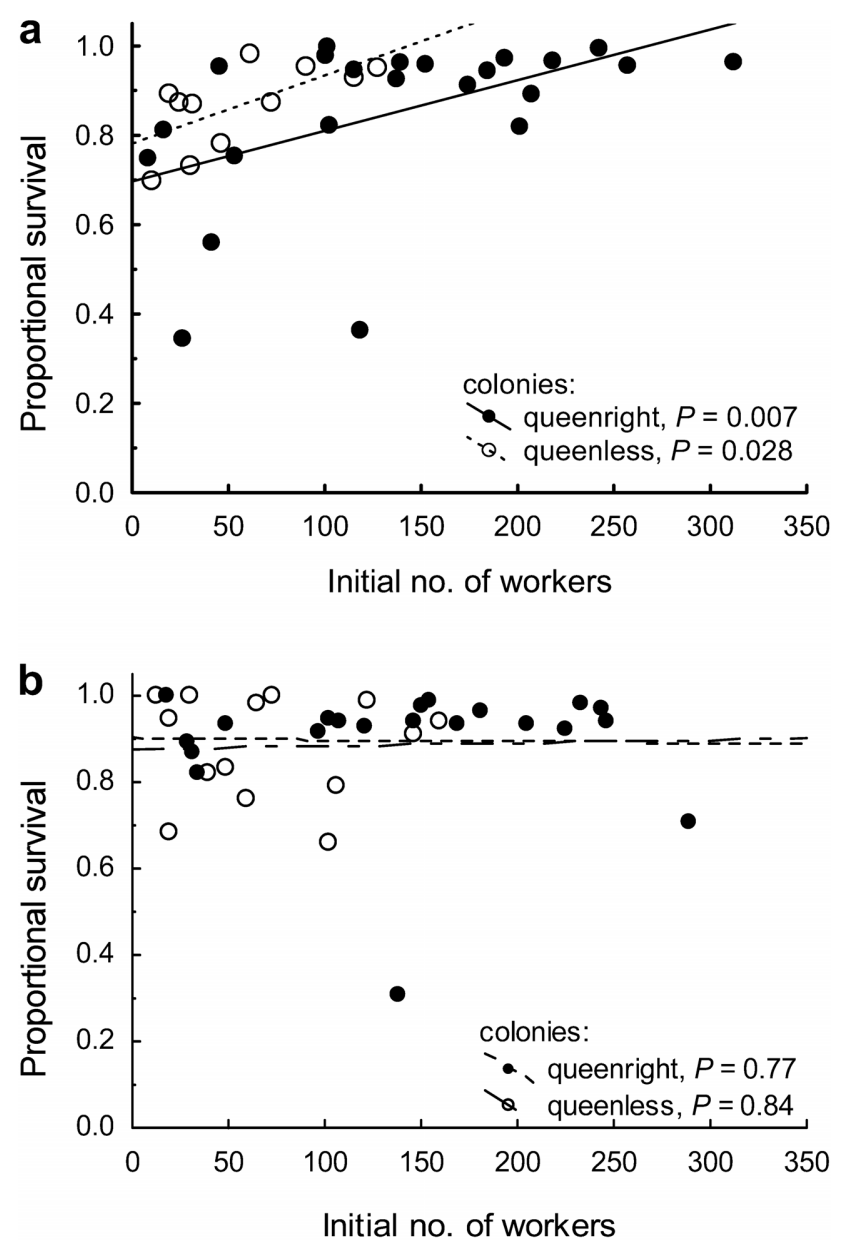

Fig. 2. Proportion of workers of the cavity-nesting ant Temnothorax crassispinus that survived during overwintering (mid December 2015 - end February 2016), in relation to the initial number of workers. There was a significant difference in the survival of workers in the nests in the experimental (from which snow cover was removed after each heavy snowfall) and "control" plots (from which no snow was removed) (GLM, $P=0.030$ ). In addition, (a) in "snowremoval" plots, survival was correlated with the initial number of workers in the nest, both for colonies with and without queens; but (b) for colonies in "control" plots there were no such correlations. Raw data are presented, but $P$ values for Pearson's correlations are calculated using transformed data for percentage survival.

2015). Thus, snow cover will only protect overwintering animals periodically (as in this experiment), and strong frost, even when short lasting, may result in high mortality.

The mortality of Temnothorax ants overwintering in nests at ground level may be high (Herbers \& Johnson, 2007; Mitrus, 2013). However, nest sites on the ground differ in different localities: for example some of them may be under leaves whereas others are on bare ground and more exposed to frost. Colonies of Temnothorax ants might relocate during winter if temperatures during the day are high (Herbers \& Johnson, 2007; pers. observ.). The artificial sites used in the experiment, which were in birch woodblocks, were readily accepted by Temnothorax ants (cf. Foitzik et al., 2003; Mitrus, 2015b). However, colonies abandoned three nests in this experiment, which indicates that ants may prefer different cavities or a different localities. Thus, closing the entrances to the artificial nests 
during the study may have affected survival compared to natural nest sites.

It is suggested that overwintering on the ground may cause Temnothorax colonies to become active early in spring (Berman et al., 2010). However, such behaviour may result in them being exposed to extreme temperatures. It is known that clustering increases the survival during winter of Leptotherax ants (Heinze \& Hölldobler, 1994; Heinze et al., 1996), and that Temnothorax colonies may unite before winter, particularly if nest sites are limited (cf. Heinze, 2008). This study shows that the fusion of colonies (resulting in an increase in the number of workers) may have an effect on their survival during some winters; mostly when frost is severe and there is lack of snow cover or such cover is thick. During this study I collected queen less colonies and those with only one queen, but in previous autumns I found colonies with several, even seven, queens (Mitrus, 2013, 2015a). It would be interesting to check if in areas where there is a higher probability of the nests being on bare exposed ground and more exposed to extreme temperatures, whether the fusion of colonies is more frequent. Differences in the percentage of such fusions may be visible especially when the availability of nest sites in autumn is large (e.g., after seasons when acorns are abundant, as some species of trees exhibit high variability in seed production between years; cf. Wesołowski et al., 2015).

ACKNOWLEDGEMENTS. This study was supported by an internal grant (No. 3/KBI/15-S) from the Department of Biosystematics, Opole University.

\section{REFERENCES}

BALE J.S. 1996: Insect cold hardiness: A matter of life and death - Eur. J. Entomol. 93: 369-382.

Bale J.S. \& HaYward S.A.L. 2010: Insect overwintering in a changing climate. - J. Exp. Biol. 213: 980-994.

Berman D.I., Alfimov A.V., Zhigulskaya Z.A. \& Leirikh A.N. 2010: Overwintering and Cold-hardiness of Ants in the Northeast of Asia. Pensoft, Sofia, Moscow, 294 pp.

Biatas B., Granieczny P., Pędzisz A. \& Mitrus S. 2011: Colony size, density and type of nesting sites of the ant Temnothorax crassispinus (Hymenoptera: Formicidae). - Opole Sci. Soc. Nat. J. 44: 185-191.

Bradshaw W.E. \& Holzapfel C.M. 2010: Insects at not so low temperature: Climate change in the temperate zone and its biotic consequences. In Denlinger D.L. \& Lee R.E. (eds): Low Temperature Biology of Insects. Cambridge University Press, Cambridge, UK, pp. 242-275.

Christensen J.H., Krishna Kumar K., Aldrian E., An S.-I., Cavalcanti I.F.A., de Castro M., Dong W., Goswami P., Hall A., KANYANGA J.K. ET AL. 2013: Climate phenomena and their relevance for future regional climate change. In Stocker T.F., Qin D., Plattner G.-K., Tignor M., Allen S.K., Boschung J., Nauels A., Xia Y., Bex V. \& Midgley P.M. (eds): Climate Change 2013: The Physical Science Basis. Contribution of Working Group I to the Fifth Assessment Report of the Intergovernmental Panel on Climate Change. Cambridge University Press, Cambridge, UK and New York, USA, pp. 1217-1308.

Convey P., Abbandonato H., Bergan F., Beumer L.T., Biersma E.M., Brathen V.S., D’Imperio L., Jensen C.K., Nilsen S., Paquin K., Stenkewitz U., Svoen M.E., Winkler J., Muller E. \& Coulson S.J. 2015: Survival of rapidly fluctuating natural low winter temperatures by High Arctic soil invertebrates. - J. Therm. Biol. 54: 111-117.

Czechowski W., Radchenko A., Czechowska W. \& Vepsäläinen K. 2012: The Ants of Poland with Reference to the Myrmecofauna of Europe. Museum and Institute of Zoology of the Polish Academy of Sciences and Natura optima dux Foundation, Warszawa, $496 \mathrm{pp}$.

Foitzik S., Strätz M. \& Heinze J. 2003: Ecology, life history and resource allocation in the ant, Leptothorax nylanderi. - J. Exp. Biol. 16: 670-680.

HAATANEN M.K., van OOIK T. \& SoRvari J. 2015: Effects of overwintering temperature on the survival of the black garden ant (Lasius niger). - J. Therm. Biol. 49-50: 112-118.

HeInZE J. 2008: Social plasticity: ecology, genetics, and the structure of ant societies. In Korb J. \& Heinze J. (eds): Ecology of Social Evolution. Springer, Berlin, pp. 129-150.

Heinze J. \& Hölldobler B. 1994: Ants in the cold. - Memorab. Zool. 48: 99-108.

Heinze J., Stah M. \& Hölldobler B. 1996: Ecophysiology of hibernation in boreal Leptothorax ants (Hymenoptera: Formicidae). - Ecoscience 3: 429-435.

HERBERs J.M. 1989: Community structure in north temperate ants: temporal and spatial variation. - Oecologia 81: 201-211.

Herbers J.M. \& Johnson A.C. 2007: Social structure and winter survival in acorn ants. - Oikos 116: 829-835.

Kożuchowski K. 2011: Klimat Polski. Nowe spojrzenie [Climate of Poland. A New Look]. Wydawnictwo Naukowe PWN, Warszawa, 293 pp. [in Polish].

Leather S.R., Walters K.F.A. \& Bale J.S. 1995: The Ecology of insect Overwintering. Cambridge University Press, Cambridge, $255 \mathrm{pp}$.

Mitrus S. 2013: Cost to the cavity-nest ant Temnothorax crassispinus (Hymenoptera: Formicidae) of overwintering aboveground. - Eur. J. Entomol. 110: 177-179.

Mitrus S. 2015a: Unexpected high overwintering survival rate of the cavity-dwelling ant Temnothorax crassispinus (Hymenoptera: Formicidae). - Entomol. Fenn. 26: 194-200.

Mitrus S. 2015b: The cavity-nest ant Temnothorax crassispinus prefers larger nests. - Insectes Soc. 62: 43-49.

Rodenhouse N.L., Christenson L.M., Parry D. \& Green L.E. 2009: Climate change effects on native fauna of northeastern forests. - Can. J. For. Res. 39: 249-263.

RUEPPELL O. \& KiRKMAN R.W. 2005: Extraordinary starvation resistance in Temnothorax rugatulus (Hymenoptera, Formicidae) colonies: Demography and adaptive behavior. - Insectes Soc. 52: 282-290.

SeIFert B. 2007: Die Ameisen Mittel- und Nordeuropas. Lutra, Görlitz, 368 pp.

Sorvari J., HaAtanen M.K. \& Vesterlund S.R. 2011: Combined effects of overwintering temperature and habitat degradation on the survival of boreal wood ant. $-J$. Insect Conserv. 15: $727-731$.

StatSoft Inc. 2014: STATISTICA (Data Analysis Software System), Ver. 12. www.statsoft.com.

Templer P.H., Schiller A.F., Fuller N.W., Socci A.M., Campbell J.L., Drake J.E. \& KunZ T.H. 2012: Impact of a reduced winter snowpack on litter arthropod abundance and diversity in a northern hardwood forest ecosystem. - Biol. Fertil. Soils $\mathbf{4 8}$ : 413-424.

WesoŁowski T., Rowinski P. \& Maziarz M. 2015: Interannual variation in tree seed production in a primeval temperate forest: does masting prevail? — Eur. J. Forest Res. 134: 99-112.

Received May 23, 2016; revised and accepted October 13, 2016 Published online October 27, 2016 